\title{
Citação:
}

Neves, MP, Costa-Pereira, R, Delariva, RL, Fialho, CB. Seasonality and interspecific competition shape individual niche variation in co-occurring tetra fish in Neotropical streams. Biotropica. 2021; 53: 329-338. https://doi.org/10.1111/btp.12879

DOI: $\underline{\text { https://doi.org/10.1111/btp.12879 }}$ 
LRH: Neves et al. RRH: SEASONAL NICHE VARIATION IN CO-OCCURRING TETRAS

\section{Seasonality and interspecific competition shape individual niche variation in co- occurring tetra fish in Neotropical streams}

Mayara Pereira Neves ${ }^{1,2}$, Raul Costa-Pereira ${ }^{3,4}$, Rosilene Luciana Delariva ${ }^{5}$, Clarice Bernhardt Fialho ${ }^{1}$

${ }^{1}$ Pós-Graduação em Biologia Animal, Laboratório de Ictiologia, Departamento de Zoologia, Instituto de Biociências, Universidade Federal do Rio Grande do Sul, Campus do Vale, Avenida Bento Gonçalves, 9500, Agronomia, 91501-970, Porto Alegre, RS, Brazil ${ }^{2}$ School of Biological and Chemical Sciences, Queen Mary University of London, London, United Kingdom

${ }^{3}$ Departamento de Biologia Animal, Instituto de Biologia, CP 6109, Universidade Estadual de Campinas - Unicamp, 13083-970, Campinas, SP, Brazil

${ }^{4}$ Evolutionary Ecology (EE), Center for Ecology, Evolution and Environmental Sciences (ce3c), Lisboa, Portugal

${ }^{5}$ Laboratório de Ictiologia, Ecologia e Biomonitoramento, Universidade Estadual do Oeste do Paraná, Centro de Ciências Biológicas e da Saúde, Rua Universitária 2069, 85819-110. Cascavel, PR, Brazil

Corresponding author: Mayara Pereira Neves, mayara-nevesbio@hotmail.com

Received___ revision accepted_.

Associate Editor: Jennifer Powers Handling Editor: Elizabeth Anderson 


\section{ABSTRACT}

The drivers of intraspecific niche variation and its effects on species interactions are still unclear, especially in species-rich Neotropical environments. Here, we investigated how ecological opportunity and interspecific competition affect the degree of individual trophic specialization and the population niche breadth in tetra fish. We studied the four ecologically similar species (Psalidodon aff. gymnodontus, P. aff. paranae, P. bifasciatus, and Bryconamericus ikaa) in subtropical headwater streams (three sites with two co-occurring species and three sites with only one species). We sampled fish in two contrasting seasons (winter/dry and summer/wet), and quantified their trophic niches using gut content analysis. Psalidodon bifasciatus was the only species distributed over all the sampled streams. We observed seasonal differences in population trophic niche breadth of $P$. bifasciatus just when this species co-occurred with $P$. aff. gymnodontus. These findings confirm the complex nature of the effects of interspecific competition, depending, for instance, on the identity of the competitor. The degree of individual specialization of $P$. bifasciatus was higher in the winter, and it was not influenced by the presence of another species. Conversely, the other two Psalidodon species studied presented greater individual specialization in the summer, when fish consumed a higher proportion of allochthonous items (terrestrial insects and seeds), and there were no effects only for $B$. ikaa. Herein, our results suggest that 
seasonality in food-resource availability is a major driver of niche variation and it has the potential to play an important role in how these similar tetra species interact and coexist. 


\section{Resumo (Português)}

Os fatores determinantes da variação intraespecífica de nicho e seus efeitos nas interações entre espécies ainda são incertos, especialmente em diversos ambientes neotropicais. Aqui, nós investigamos como a oportunidade ecológica e a competição interespecífica afetam o grau de especialização individual e a amplitude de nicho populacional em lambaris. Nós estudamos o nicho trófico de quatro espécies de lambaris ecologicamente similares (Psalidodon aff. gymnodontus, $P$. aff. paranae, P. bifasciatus e Bryconamericus ikaa) em seis riachos de cabeceira subtropicais (três riachos com pares de espécies de co-ocorrência e três locais com apenas uma espécie). Nós amostramos os peixes em duas estações contrastantes (inverno/seco e verão/chuvoso) e quantificamos seus nichos tróficos usando análise de conteúdo estomacal. Psalidodon bifasciatus foi a única espécie amostrada em todos os riachos. Nós observamos diferenças significativas na amplitude de nicho trófico de $P$. bifasciatus entre estações apenas em coocorrência com $P$. aff. gymnodontus. Nossos resultados confirmam a natureza complexa dos efeitos da competição interespecífica,_dependendo, por exemplo, da identidade do competidor. O grau de especialização individual de $P$. bifasciatus foi maior no inverno, e não foi influenciado pela presença de outra espécie. Por outro lado, as outras duas espécies de Psalidodon apresentaram maior especialização individual no verão, quando os peixes consumiram uma proporção maior de itens 
alóctones (insetos e sementes terrestres), e não houve efeitos apenas para B. ikaa.

Aqui, nossos resultados sugerem que a sazonalidade na disponibilidade de

recursos alimentares é o principal fator de variação de nicho e tem o potencial de desempenhar um papel importante na maneira como essas espécies de lambaris similares interagem e coexistem. 


\section{KEY WORDS}

Co-occurrence; freshwater; gut contents; individual specialization; southern Brazil; trophic niche breadth 


\section{INTRODUCTION}

Traditionally, ecological niches have been measured at population level, indirectly assuming that individuals are functionally equivalent (Bolnick et al., 2003). However, in the last two decades it has been widely recognized that intrapopulation niche variation is common in nature and has relevant implications for diverse ecological and evolutionary processes (Bolnick et al., 2003; 2011; Araújo, Bolnick \& Layaman, 2011; Ingram, CostaPereira \& Araújo, 2018). Individual niche specialization occurs when generalist species are composed of specialist individuals that use only narrow subsets of the total niche population (Bolnick et al., 2003). Essentially, documenting individual specialization in nature allows us to better understand how organisms use and partition resources across different organizational levels (Bolnick et al., 2003; Evangelista, Boiche, Lecerf \& Cucherousset, 2014). However, the causes of intraspecific niche variation and how it may affect species interactions are still unclear (Hart, Schreiber \& Levine, 2016; Costa-Pereira, Rudolf, Souza \& Araújo, 2018), especially in highly diverse environments (Araújo \& Costa-Pereira, 2013), such as the Neotropical freshwaters.

Foraging theory and recent empirical evidence indicate that intra- and interspecific competition, and ecological opportunity (i.e., diversity of available resources, sensu Araújo et al., 2011) are major factors driving niche variation within populations (Araújo et al., 2011; Costa-Pereira et al., 2018). Regarding interspecific competition, the Niche Variation Hypothesis states that ecological release from competing species leads to population niche expansion largely via increased between-individual variation (Van Valen, 1965). However, there are conflicting results in the empirical literature, as interspecific competition has a negative or positive effect on the degree of individual specialization (Bolnick et al., 2010; Araújo et al., 2011; Costa-Pereira, Araújo, Souza \& Ingram, 2019). In turn, empirical 
evidence strongly suggests that intraspecific competition favours individual niche variation (Svanback \& Bolnick, 2007; Araújo et al., 2011). The Optimum Foraging Theory assumes that individuals tend to consume energetically favourable food (Stephens \& Krebs, 1986). Because intraspecific competition tends to decrease the availability of preferred resources, individuals are expected to diverge in their trophic niches by consuming alternative items (Svanback \& Bolnick, 2005). Therefore, resource depletion by both conspecifics and heterospecifics can affect niche variation (Svanbäck \& Bolnick, 2005; Araújo et al., 2011), but this effect also depends on environmental prey availability.

Ecological opportunity is also an important driver of individual niche variation. The diversity of available prey can vary independently of the number or abundance of competing species (Araújo et al., 2011; Costa-Pereira et al., 2018). Considering both seasonal resource dynamics and consumer niche variability, empirical studies support the hypothesis that the degree of individual specialization should increase with periods of greater resource diversity (Araújo et al., 2011; Costa-Pereira, Tavares, Camargo \& Araujo, 2017). In Neotropical freshwater ecosystems, higher ecological opportunity during rainy and hot periods often leads to a greater population trophic niche breadth and higher individual variation (Costa-Pereira et al., 2017; Quirino, Carniatto, Gaiotto \& Fugi, 2017; Silva, Gubiani, Neves \& Delariva, 2017; Cunha, Wolff \& Hahn, 2018; Neves, Silva, Baumgartner, Baumgartner \& Delariva, 2018).

Subtropical streams are dynamic and diverse environments markedly affected by seasonal variation in temperature and precipitation (Dudgeon, 2008). The winter is the dry period, when resource diversity is mainly supported by autochthonous inputs (Pujarra et al., 2017). In turn, rains are concentrated in the summer, when resource diversity increases substantially due to inputs of allochthonous materials (Lisboa, Silva, Siegloch, Júnior 
\&Petrucio, 2015; Tonin et al., 2017). These marked seasonal variations in resource availability in subtropical streams are expected to shape population and individual niches in line with the Optimal Foraging Theory. However, their effects should also depend on the magnitude of interspecific competition (Costa-Pereira et al. 2017).

In Neotropical streams, several ecologically similar fish species co-occur and potentially compete for common resources. How these species interact locally have been widely studied in an interspecific perspective, however ecological studies have rarely taken into account intraspecific variations (Neves, Delariva \& Wolff, 2015; Baldasso, Wolff, Neves \& Delariva, 2019; Pini et al., 2019). Among these similar co-occurring species, small characids (tetra fish) exhibit a striking diversity in morphology and life history across species, but also conspicuous variation within populations (Bonato, Burres, Fialho, Armbruster, 2017; Silva et al., 2017; Garita-Alvarado, Barluenga \& Ornelas-García, 2018). South American small-sized characids, mainly Asyanax, Psalidodon and Bryconamericus species, are omnivorous generalist fish commonly found in the water column of streams (Bonato et al., 2017; Neves et al., 2018; Delariva \& Neves, 2020). Characids species are considered as opportunistic foragers due to their ability to shift their diets according to the seasonal abundance of resources (Corrêa, Albrecht, Hahn, 2011; Juncos, Milano, Macchi \& Vigliano, 2015; Silva et al., 2017; Neves et al., 2018). Still, due to their ecological similarities, characid species exhibit high diet similarity and thus are expected to compete for food resources with each other. Finally, considering that streams are threatened environments due to anthropogenic pressures (Castro \& Polaz, 2020), knowing the factors that influence the species' niche is essential for the management and conservation of these ecosystems. 
Here we studied trophic niche variation across individuals and populations of four species of tetra fish (genera Psalidodon and Bryconamericus) in Neotropical headwater streams. Due to their morphological (Figure 1; Baumgartner et al., 2012), resource and microhabitat use similarities, species from these genera have high competitive potential. First, we described the diet of these species and tested how seasonality affects individual trophic specialization and population niche variation. We expected that in the summer, tetras would exhibit a wider trophic population niche and greater trophic specialization at the individual level, due to a greater diversity of available feeding resources. Then, we focused on one widely distributed species (Delariva et al., 2018), Psalidodon bifasciatus, which is found both in streams with and without other characid species, to test the effects of seasonality and interspecific competition on individual specialization. Then, based on the Niche Variation Hypothesis (Van Valen, 1965), we expected to observe narrow population niches and lower individual niche specialization in populations of $P$. bifasciatus cooccurring with potential interspecific competitors.

\section{METHODS}

\subsection{Study area}

The Piquiri and Iguaçu rivers are direct tributaries of the Paraná River, the second largest basin in South America (Agostinho, Thomaz, Minte-Vera \& Winemiller, 2000). This area is considered of great ecological relevance and high priority of action due to the fish richness, high degree of endemism ( $70 \%$ of the fish species in Iguaçu river basin, Baumgartner et al., 2012). In addition, the fish fauna is highly threatened by anthropogenic pressures from the construction of hydroelectric projects, agriculture and urbanization, which highlights the need for conservation (Parolin, Volkmer-Ribeiro \& Leandrini, 2010). 
Originally, vegetation was composed by seasonal semideciduous forest and mixed ombrophilous forest. However, currently forested areas are mostly confined to conservation areas protected by law, such as parks and biological reserves. The climate of this ecoregion is humid subtropical Cfa (Köppen, 1936), with hot humid summers and cool and dry winters (Baumgartner et al. 2012). The mean annual precipitation in this region varies between 1275 and $2250 \mathrm{~mm}$. The mean minimum and maximum temperatures range between 4 and $10{ }^{\circ} \mathrm{C}$ in winter, and 23 and $33{ }^{\circ} \mathrm{C}$ in summer (Baumgartner et al., 2012).

\subsection{Sampling}

We sampled six headwater streams $\left(2^{\text {nd }}\right.$ and $3^{\text {th }}$ orders - Figure S1, Table S1) and collected all small characids species found: Psalidodon aff. paranae (Eigenmann, 1914), Psalidodon bifasciatus (Garavello \& Sampaio, 2010), Psalidodon aff. gymnodontus (Eigenmann, 1911) and Bryconamericus ikaa Casciotta, Almirón \& Azpelicueta, 2004 (Figure 1). Psalidodon species were recently relocated to the genus Psalidodon by Terán, Benitez \& Mirande (2020), and until then they were recognized as Astyanax aff. gymnodontus, Astyanax aff. paranae, and Astyanax bifasciatus. Characidae species are the most abundant species in the sampled streams and their abundance varied from 55.4 to $83.3 \%$ of the fish assemblage. In addition to their high abundance, we choose to investigate these species due to their phylogenetic proximity and morphological similarity that make them potential competitors. In our samples, $P$. bifasciatus was abundant in streams with co-occurrence characid species (mean numerical abundance: $40.5 \%$ ) and highly abundant in streams without the presence of another Characidae species (77.9\%). Psalidodon aff. gymnodontus (relative abundance 49.5\%), P. aff. parane (5.6\%) and B. ikaa (12.9\%) were restricted to one location each (S1, 
S3, and S2, respectively). In summary, our study design includes three sites (S1, S2, and S3) with two characid species co-occurring ( $P$. aff. gymnodontus x $P$. bifasciatus, $P$. aff. paranae $\times$ P. bifasciatus, B. ikaa $\times$ P. bifasciatus, respectively), and three sites (S4, S5, and S6) with only characid species (P. bifasciatus). Due to clear ecological (i.e., trophic, behavioural, microhabitat use) and morphological differences between Characids and other taxonomic families, we did not consider other species of Siluriformes and Cyprinodontiformes as potential direct interspecific competitors. In addition, we did not observe any predatory species of Characidae species, as well as in previous studies carried out in streams in the study region (Neves et al., 2015; Delariva et al., 2018; Baldasso et al., 2019).

\section{Figure 1}

We sampled fish in July (winter) and December (summer) 2017. According to the historical climate series of the region, 2017 represents a typical year with cold and dry winter, and hot and rainy summer (Figure S2). There is solid evidence that seasonal variation in precipitation drastically alter the diversity and abundance of resources for fish (Novakowski, Hahn \& Fugi, 2008, Soares et al., 2013; Correa \& Winemiller, 2014; Tonin et al., 2017), including streams in our study region (Pujarra et al., 2017). In each season, we realized one sampling event per stream. We conducted the fish sampling in reaches of $50 \mathrm{~m}$ using electrofishing with three passes of $40 \mathrm{~min}$. After capture, specimens were anaesthetized, fixed in 10\% formalin, and preserved in 70\% alcohol. We collected fish with authorization from the Instituto Chico Mendes de Conservação da Biodiversidade (ICMBio) (license number 25039-1) and approved by the Ethics Committee on Animal Use 
of the Universidade Federal do Rio Grande do Sul (CEUA - 32734) in accordance with protocols in their ethical and methodological aspects for the use of fish.

\subsection{Laboratory procedures}

We identified specimens in the laboratory according to specific identification keys (Baumgartner et al., 2012; Ota, Deprá, Graça \& Pavanelli, 2018). To avoid bias caused by ontogenetic variations, we selected 403 adult individuals (Table S2). Voucher specimens were deposited in the fish collection of the Departamento de Zoologia, Universidade Federal do Rio Grande do Sul.

We analyzed the stomach contents under stereoscopic and optical microscope and feeding items were identified to the lowest possible taxonomic level, using specific literature for the algae (Bicudo \& Bicudo, 1970) and invertebrates (Mugnai, Nessimian \& Baptista, 2010). We quantified the proportion of feeding items in each individual's diet following the volumetric method (Hyslop, 1980) using graduated test tubes and a glass counting plate (Hellawell \& Abel, 1971).

\subsection{Data analysis}

\subsubsection{Population niche breadth}

We performed all statistical analyses in R version 3.5.2 (R Core Team, 2019). To investigate seasonality in population niche breath, we used a permutational analysis of multivariate dispersions (PERMDISP; Anderson, 2006). PERMDISP was applied based on the distance of samples (diet of individuals) from the centroid of the group (species-season). In this case, distance to the centroid (D), obtained by the average of the distance of the individuals of each group (species/season) to centroid, corresponds to a metric analogous to population niche breadth (Correa \& 
Winemiller, 2014), i.e. in populations with high D value, individuals tend to vary more from diet to average population. The distance to the centroid of group defined a priori (species/season) was calculated using a principal coordinate analysis (PCoA). Calculation of the centroid of the group was performed using the dissimilarity measure of Bray-Curtis, allowing the comparison of the average dissimilarity in $n$-individual observations within the group. To test the null hypothesis that niche breadth did not differ among the groups, we calculated a statistical $\mathrm{F}$ to compare the average distance of each sample to the centroid of the group. Subsequently, we obtained P-values through 9,999 permutations of the residues of least squares (Anderson, 2006). We made post hoc pair-wise comparisons among species and between seasons using Tukey's honest significant difference method. Finally, when PERMDISP revealed seasonal differences in the population niche breadth, we performed a similarity percentage analysis (SIMPER) using Bray-Curtis dissimilarity (Clarke, 1993) to identify feeding items that contributed most to the intraspecific dissimilarity between the seasons. We run PERMDISP and SIMPER in the vegan package (Oksanen et al., 2019).

\subsubsection{Individual specialization}

First, we calculated for each individual the proportional similarity index (PSi; Schoener, 1968) using the following formula:

$$
\mathrm{PS}_{i}=1-0.5 \sum_{j}\left|p_{j i}-q_{j}\right|=\sum_{j} \min \left(p_{j}, q_{j}\right)
$$

Where the variable $p_{i \mathrm{j}}$ describing the proportion of the $j$ th all resources category in individual $i$ 's diet, $q_{j}$ is the proportion of the $j$ th resource category in the population's niche. 
Then, the population-wide prevalence of individual specialization (IS) is then measured by the average of individuals' PSi values. IS measures the average overlap between individuals' niche and the population niche (Schoener, 1968; Bolnick, Yang, Fordyce, Davis \& Svanbäck, 2002). As proposed by Bolnick, Svanbäck, Araújo \& Persson (2007), instead of IS we used a more intuitive metric of individual specialization: V $=1-$ IS. High values of V (closer to 1) indicate that individuals are more specialized (Bolnick et al., 2007). We performed these metrics using the RInSp package (Zaccarelli, Bolnick \& Mancinelli, 2013).

\subsubsection{Drivers of individual specialization and population trophic niche}

To test the effects of interspecific competition and seasonality on the degree of specialization and trophic niche breadth, we focused on P. bifasciatus due to its wide distribution (three sites: allopatric; three sites: in co-occurrence with other Characidae species). We constructed Generalized Linear Mixed Model (GLMM) with beta family distribution, including PSi values and D (distance to centroid, PERMDISP) as response variables; seasons (summer or winter) and presence of potential competitor (other Characidae species; as category variable) and their interaction as fixed factors, and site as a random factor. We did visual inspection of residual plots to check model assumption and the models were performed using the glmmTMB package (Brooks et al., 2017). To identify differences in individual specialization between seasons and species, we perform a Generalized Linear Model (GLM) using beta family distribution in betareg package (Cribari-Neto \& Zeileis, 2010), which was designed for analysing the proportional data with values bounded between 0 and 1 . 


\section{RESULTS}

\subsection{Diet composition}

We analysed the diet of a total of 403 individuals. Tetra fish consumed a wide diversity of feeding items (38), ranging from aquatic invertebrates to leaves and seeds (Table S2). In terms of frequency of occurrence, the most common items consumed by species were aquatic insects (43.4\%); sediment/detritus (11.6\%), seeds/leaves (17.1\%), and Hymenoptera (8.1\%). The rarest were Acarina (0.16\%), Conchostracoda $(0.16 \%)$, Hemiptera nymphy $(0.16 \%)$, Plecoptera adult $(0.16 \%)$, Bivalvia $(0.08 \%)$ and Oniscidae (0.08\%). In general, Psalidodon species consumed greater proportions of allochthonous resources in the summer ( $P$. aff gymnodontus: $73.6 \% ; P$. bifasciatus: 75.7\%; $P$. aff. paranae: $55.5 \%$ ), except $B$. ikaa (Table S2). Psalidodon aff. gymnodontus was classified as omnivorous and consumed predominantly items of allochthonous origin in both seasons, leaves $(29.9 \%)$ and seeds $(26.7 \%)$ in the winter, and there was an increase in the consumption of Coleoptera (22.2\%) and Hymenoptera (12.1\%) in the summer. Psalidodon aff. paranae presented an insectivorous habit, whose consumption in the winter was based on aquatic insects (45.6\%) and Hymenoptera (29.8\%), and in the summer, Coleoptera (34.1\%) and Auchenorrhyncha (13.4\%). Psalidodon bifasciatus consumed mainly aquatic insects $(27 \%)$ and sediment/detritus $(20.5 \%)$ in the winter, and seeds $(61.3 \%)$ in the summer, and due to this substitution, it was classified as omnivorous. Bryconamericus ikaa exhibited an insectivorous habit with high consumption of aquatic insects in both seasons (Table S2), mainly Ephemeroptera (44.7\% in the winter, and $18.2 \%$ in the summer) and Trichoptera (19.6\% in the winter, and $16 \%$ in the summer).

\subsection{Population niche breadth}


Overall, there was no influence of seasonality on population niche breadth of species (PERMDISP; Table 1; Figure 2; Table S3), except for $P$. aff. gymnodontus and $P$. bifasciatus in 'S1' and $P$. aff. paranae in 'S2'. Specifically, in the stream 'S1', in the winter, $P$. bifasciatus exhibited a greater trophic niche breadth $(0.61$, Table 1$)$, and decreased in the summer $(0,52)$. Already, $P$. aff. gymnodontus presented a lower value $(0.58)$ in the winter, and increased in the summer (0.63). Also, in the stream 'S2' $P$. aff. paranae significantly broadened its alimentary spectrum in the summer (winter: 0.35 ; summer: 0.61), but there was no significant seasonal difference for P. bifasciatus. In other streams, no significant differences were observed in trophic niche breadth of $P$. bifasciatus between the seasons (Table 1). In general, according to the SIMPER analysis, seasonal differences observed in the diet of the species were related to the higher consumption of seeds in summer (Table S4).

\section{Table 1}

Figure 2

\subsection{Individual specialization}

The degree of individual specialization in P. bifasciatus was influenced by seasonality $(\beta:-0.99 ; P<0.001)$, but not by co-occurrence with Characid species $(\beta: 0.39 ; P$ $=0.07$; Table 2; Figure 3). In general, P. bifasciatus presented high individual specialization in the winter (Figure 3, Table 2). Conversely, the other two Psalidodon species ( $P$. aff. gymnodontus, $P$. aff. paranae and B. ikaa), exhibited higher individual specialization in the summer (Figure 3, Table 3). There were no effects of seasonality on the degree of individual specialization only for B. ikaa (Table 3). 


\section{Figure 3}

Table 2

Table 3

\section{DISCUSSION}

Tetra fish presented seasonal diet variation mainly associated with greater consumption of allochtonous resources in the summer. However, this temporal variation did not result in differences in population trophic niche breadth across seasons, except for $P$. aff. paranae and for $P$. bifasciatus when in co-occurrence with $P$. aff. gymnodontus. In turn, the degree of individual specialization of the studied species differed largely between seasons. In agreement to the Optimal Foraging theory, $P$. bifasciatus exhibited greater individual specialization in the winter regardless of presence of potential competitors. It suggests a possible preference of $P$. bifasciatus for autochthonous resources (i.e., aquatic invertebrates), which has been corroborated by stable isotope analyses (unpublished data). The other two Psalidodon species exhibited increased individual specialization in the summer, which may be related to the seasonal increment in resource diversity during this season, mainly allochtonous resources. The absence of seasonal difference in the degree of individual specialization of $B$. ikaa may be related to the high consumption of aquatic insects in both seasons. These findings reinforce the key role that seasonal environmental variation plays in shaping niche variation both within and between species, which may have important implications for how species interact temporally, mainly for congeneric species. Environmental prey availability in Neotropical streams is strongly determined by the continuous precipitation in the austral summer (Novakowski et al., 2008). Specifically, 
although high precipitation increases water flow and hinders establishment of macrobenthic community, it increments the input of allochthonous food resources (i.e., terrestrial invertebrates, fruits, seeds), and, consequently, boosts the diversity of available resources (Quirino, Carniatto, Gaiotto \& Fugi, 2015; Pujarra et al., 2017). According to the foraging theory, this seasonal increment in ecological opportunity would result not only in a population niche expansion but also lead to an overall increase in individual trophic variation (Araújo et al., 2011; Costa-Pereira et al., 2017). Surprisingly, here we did not observe seasonal differences in the population trophic niche breadth, but there were seasonal variations on the degree of individual specialization of species. This pattern is in line with the expected by the individual release hypothesis, in which individual niche expansion is offset by decreased variation among individuals, so the population niche remains unchanged (Bolnick et al., 2010). Thus, according to the optimal foraging theory, if an initially heterogeneous population experiences reduced environmental prey availability, all individuals can become more generalist and begin to include previously neglected food items in their diets (Stephens \& Krebs 1986).

In periods of higher diversity of available resources, the degree of individual specialization is expected to increase (Lowe-McConnell, 1999; Araújo et al., 2011; CostaPereira et al., 2017; Cunha et al., 2018). Indeed, this pattern was observed for $P$. aff. gymnodontus and $P$. aff. paranae. These species exhibited greater individual specialization in the summer (greater ecological opportunity). However, we acknowledge this result is based in the presence of these species in only one stream ( $P$. aff. gymnodontus in $\mathrm{S} 1$ and $P$. aff. paranae in S2) and therefore future studies should expand the spatial scale of these investigations. On the other hand, P. bifasciatus, the most widely distributed species in our system (Delariva et al., 2018), exhibited a distinct response with greater individual 
specialization in the winter (dry season). This surprising result indicates that higher ecological opportunity may not always strongly favor individual niche variation as predicted by foraging theory and observed in most of the empirical studies. For example, the relative importance of ecological opportunity in determining individual specialization in communities can be relatively weak when compared to other ecological interactions (i.e., intraspecific competition, predation) (Costa-Pereira et al. 2018).

The distinct pattern of individual specialization displayed by P. bifasciatus suggests that there may be other drivers of niche variation beyond seasonality. In this sense, interspecific competition can reduce the ecological opportunity because profitable common resources are depleted by heterospecific competitors (Evangelista et al., 2014). The stream 'S1'was the only case where the population trophic niche of $P$. bifasciatus differed significantly between seasons. Specifically, P. bifasciatus expanded significantly its trophic niche in the winter. However, contrarily, in the same stream $P$. aff. gymnodontus expanded its niche in the summer. This species-specific pattern can be related to relative abundance and competitive pressure. Interestingly, in this stream, $P$. aff. gymnodontus had higher abundance than $P$. bifasciatus, while in another streams, $P$. bifasciatus had higher abundance than another characid species. In addition, $P$. aff. gymnodontus has high morphological similarity (e.g. body size) with $P$. bifasciatus than another species ( $P$. aff. paranae and $B . i k a a$ ). We acknowledge that this pattern emerged in only one stream and its potential explanations should be considered carefully. Future investigations should integrate species traits (e.g. body size) and their relative abundances to uncover if $P$. aff. gymnodontus has the potential to exert greater competitive pressure on P. bifasciatus. Further, perhaps interspecific competition is alleviated by seasonal variations in resources and opposite patterns of trophic niche contraction between these two species. Our findings 
confirm the complex nature of the effects of interspecific competition, depending, for instance, on the identity of the competitor (Bolnick et al., 2010; Barros, Zuanon \& Deus, 2017; Costa-Pereira et al., 2018).

The presence of interspecific, closely related potential competitors (i.e., family Characidae) had little explanatory power on the degree of individual specialization of $P$. bifasciatus. Thus, resource seasonality seems to be a more important driver of individual niche variation in this species. According to Bolnick et al. (2010) interspecific competition can increase or decrease individual specialization depending on the ecological context. Other factors like intraspecific competition can also affect and interact to determine the degree of individual specialization. Herein, the tendency towards greater individual specialization of $P$. bifasciatus in the winter may indicate a possible strategy that will give it success in periods of greater food shortages. Decreasing intraspecific competition via divergence in individual's foraging decisions can be important for this species when resources are scarce. In addition, a trophic generalist strategy in periods of greater ecological opportunity can increase the individual-level fitness (Costa-Pereira, Toscano, Souza, Ingram \& Araújo 2019). Thus, different combinations of these ecological drivers in a temporal context could lead to shifts in relative individual specialization and interaction between species, and consequently affect the coexistence of species and distribution patterns (Costa-Pereira et al., 2018). Seasonality has the potential to modulate the local maintenance of populations of species with highly competitive potential (Silva et al., 2017; Neves et al., 2018).

In conclusion, our results emphasize the importance of environmental seasonality on shaping niche variation within and across species. Importantly, these effects seem to be species-specific and context-dependent. While three of the studied species exhibit greater 
individual specialization in the rainy season, likely as a result of the increased diversity of available resources, $P$. bifasciatus presented greater individual specialization occurred in the dry season (Figure 4). These seasonal changes in the links between individual consumers and their prey can play an important role in altering temporally the magnitude of intra and interspecific competition. Therefore, our results suggest that this temporal dimension of niche variation within-populations has the potential to affect the coexistence of similar species, which is a promising avenue for future research. Herein, we conclude that the understanding of the dynamics of food webs within subtropical headwater streams can benefit from a perspective of intraspecific niche variation.

\section{ACKNOWLEDGMENTS}

We are thankful to the Universidade Estadual do Oeste do Paraná for support and infrastructure during field expeditions. To the members of the Laboratório de Ictiologia, Ecologia e Biomonitoramento (LIEB), Pini S. and Neves J. F. for helping during field collections. To the Laboratório de Ictiologia Universidade Federal do Rio Grande do Sul, especially to Silva P. C., Netto-Ferreira, A. L. and Malabarba, L. R. during the identifying process of the specimens. To Gonsales P. L. B. for helping for helping in building the schematic figure. To the Conselho Nacional de Desenvolvimento Científico e Tecnológico for granting a PhD scholarship (CNPq Proc. 152847/2016-2, to MPN) and to the Programa de Pós-Graduação em Biologia Animal/UFRGS.

\section{DISCLOSURE STATEMENTS}

\section{Conflict of Interest}


The corresponding author confirms on behalf of all authors that there have been no involvements that might raise the question of bias in the work reported or in the conclusions, implications, or opinions stated.

\section{DATA AVAILABILITY}

Data available from the Dryad Digital Repository:

https://doi.org/10.5061/dryad.tajq2bvx5 (Nevel et al. 2020). 


\section{REFERENCES}

Agostinho, A. A., Thomaz, S. M., Minte-Vera, C. V., \& Winemiller, K.O. (2000).

Biodiversity in the High Paraná River floodplain. In B. Gopal, W. J. Junk \& J. A. Davis

(Eds), Biodiversity in wetlands: assessment, function and conservation (pp. 89-118). Leiden, Netherlands: Backhuys Publishers.

Anderson, M. J. (2006). Distance based tests for homogeneity of multivariate dispersions. Biometrics, 62, 245-253.

Araújo, M. S., \& Costa-Pereira, R. (2013). Latitudinal gradients in intraspecific ecological diversity. Biology letters, 9(6), 20130778.

Araújo, M. S., Bolnick, D. I., \& Layaman, C. A. (2011). The ecological causes of individual specialisation. Ecology letters. 14, 948-958.

Baldasso, M. C., Wolff, L. L., Neves, M. P., \& Delariva, R. L. (2019). Ecomorphological variations and food supply drive trophic relationships in the fish fauna of a pristine neotropical stream. Environmental Biology of Fishes, 102, 783-800.

Barros, G., Zuanon, J., \& Deus, C. (2017). Effects of species co-occurrence on the trophicniche breadth of characids in Amazon forest streams. Journal of Fish Biology, 90, 326-340. Baumgartner G., Pavanelli, C. S., Baumgartner, D., Bifi, A. G., Debona, T., \& Frana, V. A. (2012). Peixes do baixo rio Iguaçu. Maringá, Paraná: EDUEM.

Bicudo, C. E. M., \& Bicudo, R. M. T. (1970). Algas de águas continentais brasileiras chave ilustrada para identificação de gêneros. São Paulo, SP: Fundação Brasileira para o Desenvolvimento do Ensino de Ciências.

Bolnick, D. I., Ingram, T., Stutz, W. E., Snowberg, L. K., Lau, O. L., \& Paull, J. S. (2010). Ecological release from interspecific competition leads to decoupled changes in population 
and individual niche width. Proceedings of the Royal Society B: Biological Sciences, 277(1689), 1789-1797.

Bolnick, D. I., Svanbäck, R., Araújo, M. S., \& Persson, L. (2007). Comparative support for the niche variation hypothesis that more generalized populations also are more heterogeneous. Proceedings of the National Academy of Sciences, 104, 10075-10079. Bolnick, D. I., Svanbäck, R., Fordyce, J. A., Yang, L. H., Davis, J. M., Hulsey, C. D., \& Forister, M. L. (2003). The Ecology of Individuals: Incidence and Implications of Individual Specialization. The American Naturalist, 161, 1-28.

Bolnick, D. I., Yang, L. H., Fordyce, J. A., Davis, J. M., \& Svanbäck, R. (2002). Measuring individual-level resource specialization. Ecology, 83(10), 2936-2941.

Bolnick, D.I., Amarasekare, P., \&Araújo, M. S., Burger, R., Levine, J. M., Novak, M., Rudolf, V. H. W., Schreiber, S. J., Urban, M. C., \& Vasseur, D. (2011). Why intraspecific trait variation matters in community ecology. Trends in Ecology \& Evolution, 26, 183-192. Bonato, K. O., Burress, E. D., Fialho, C. B., \& Armbruster, J. (2017). Resource partitioning among syntopic Characidae corroborated by gut content and stable isotope analyses. Hydrobiologia, 805, 1-14.

Brooks, M. E., Kristensen, K., van Benthem, K. J., Magnusson, A., Berg, C. W., Nielsen, A., Skaug, H. J., Maechler, M., \& Bolker, B. M. (2017). glmmTMB Balances Speed and Flexibility Among Packages for Zero-inflated Generalized Linear Mixed Modeling. The $R$ Journal, 9, 378-400.

Castro, R., \& Polaz, C. N. (2020). Small-sized fish: the largest and most threatened portion of the megadiverse neotropical freshwater fish fauna. Biota Neotropica, 20, e20180683. Clarke, K. R. (1993). Non-parametric multivariate analyses of changes in community structure. Australian Journal of Ecology, 18, 117-143. 
Corrêa, C. E., Albrecht, M. P., \& Hahn, N. S. (2011). Patterns of niche breadth and feeding overlap of the fish fauna in the seasonal Brazilian Pantanal, Cuiabá River basin. Neotropical Ichthyology, 9, 637-646.

Correa, S. B., \& Winemiller, K. O. (2014). Niche partitioning among frugivorous fishes in response to fluctuating resources in the Amazonian floodplain forest. Ecology, 95, 210-224. Costa-Pereira, R., Araújo, M. S., Souza, F. L., \& Ingram, T. (2019). Competition and resource breadth shape niche variation and overlap in multiple trophic dimensions. Proceedings of the Royal Society B, 286(1902), 20190369.

Costa-Pereira, R., Rudolf, V. H., Souza, F. L., \& Araújo, M. S. (2018). Drivers of individual niche variation in coexisting species. Journal of Animal Ecology, 87, 1452-1464.

Costa-Pereira, R., Tavares, L. E., Camargo, P. B., \& Araujo, M. S. (2017). Seasonal population and individual niche dynamics in a tetra fish in the Pantanal wetlands. Biotropica, $49,531-538$.

Costa-Pereira, R., Toscano, B., Souza, F. L., Ingram, T., \& Araújo M. S. (2019). Individual niche trajectories drive fitness variation. Functional Ecology, 33(9), 1734-1745.

Cribari-Neto, F., \& Zeileis, A. (2010). Beta Regression in R. Journal of Statistical Software, $34,1-24$.

Cunha, A. F., Wolff, L. L., \& Hahn, N. S. (2018). Seasonal changes at population and individual levels in the diet of juvenile catfish in a Neotropical floodplain. Journal of Freshwater Ecology, 33, 273-284.

Delariva, R. L., \& Neves, M. P. (2020). Morphological traits correlated with resource partitioning among small characin fish species coexisting in a Neotropical river. Ecology of Freshwater Fish, 00, 1-14. 
Delariva, R. L., Neves, M. P., Larentis, C., Kliemann, B. C. K., Baldasso, M. C., \& Wolff, L. L. (2018). Fish fauna in forested and rural streams from an ecoregion of high endemism, lower Iguaçu River basin, Brazil. Biota Neotropica, 18, e20170459.

Dudgeon, D. (2008). Tropical Stream Ecology. Series: Aquatic Ecology Serie. London, UK: Academic Press.

Evangelista, C., Boiche, A., Lecerf, A., \& Cucherousset, J. (2014). Ecological opportunities and intraspecific competition alter trophic niche specialization in an opportunistic stream predator. Journal of Animal Ecology, 83, 1025-1034.

Garita-Alvarado, C. A., Barluenga, M., \& Ornelas-García, C. P. (2018). Parallel evolution of morphs of Astyanax species (Teleostei: Characidae) in México and Central America. Biological Journal of the Linnean Society, 124, 706-717.

Hart, S. P., Schreiber, S. J., \& Levine, J. M. (2016). How variation between individuals affects species coexistence. Ecology Letters, 19, 825-838.

Hellawell, J. M., \& Abel, R. (1971). A rapid volumetric method for the analysis of the food of fishes. Journal of Fish Biology, 3, 29-37.

Hyslop, E. J. (1980). Stomach content analysis: a review of methods and their application. J Journal of Fish Biology, 17, 411-429.

Ingram, T., Costa-Pereira, R., \& Araújo, M. S. (2018). The dimensionality of individual niche variation. Ecology, 99, 536-549.

Juncos, R., Milano, D., Macchi, P. J., \& Vigliano, P. H. (2015). Niche segregation facilitates coexistence between native and introduced fishes in a deep Patagonian lake. Hydrobiologia, $747,53-67$.

Köppen, W. 1936. Das geographische System der Klimate. In Köppen, W., and R. Geiger R. (Eds). Handbuch der Klimato-logie, 44 pp. Gebrüder Borntraeger, Berlin. 
Lisboa, L. K., Silva, A. L. L., Siegloch, A. E., Júnior, J. F. G., \& Petrucio, M. M. (2015).

Temporal dynamics of allochthonous coarse particulate organic matter in a subtropical

Atlantic rainforest Brazilian stream. Marine and Freshwater Research, 66, 674-680.

Lowe-McConnell, R. H. (1999). Estudos ecológicos de comunidade de peixes tropicais. São Paulo, SP: EDUSP.

Mugnai, R., Nessimian, J. L., \& Baptista, D. F. (2010). Manual de identificação de macroinvertebrados aquáticos do estado do Rio de Janeiro. Rio de Janeiro, RJ: Technical Boocks.

Neves, M. P., Delariva, R. L., \& Wolff, L. L. (2015). Diet and ecomorphological relationships of an endemic, species-poor fish assemblage in a stream in the Iguaçu National Park. Neotropical Ichthyology, 13(1), 245-254.

Neves, M. P., Silva, J. C., Baumgartner, D., Baumgartner, G., \& Delariva, R. L. (2018). Is resource partitioning the key? The role of intra-interspecific variation in coexistence among five small endemic fish species (Characidae) in subtropical rivers. Journal of Fish Biology, $93,238-249$.

Neves, M.P., R. Costa-Pereira, R. L. Delariva, C. B. Fialho. 2020. Data from: Seasonality and interspecific competition shape individual niche variation in co-occurring tetra fish in Neotropical streams. Dryad Digital Repository. doi:10.5061/dryad.taja2bvx5

Novakowski, G. C., N. S. Hahn, and R. Fugi. 2008. Diet seasonality and food overlap of the fish assemblage in a pantanal pond. Neotrop. Ichthyol. 6: 567-576.

Oksanen, J., Blanchet, F. G., Friendly, M., Kindt, R., Legendre, P., McGlim, D., ... \& Wagner, H. (2019). The vegan package. Community Ecology Package. R package version 2.5-5. https://CRAN.R-project.org/package=vegan. 
Ota, R. R., Deprá, G. D. C., Graça, W. J. D., \& Pavanelli, C. S. (2018). Peixes da planície de inundação do alto rio Paraná e áreas adjacentes: revised, annotated and updated. Neotropical Ichthyology, 16, e170094.

package version 1.4.6. https://CRAN.R-project.org/package=emmeans

Parolin, M., Volkmer-Ribeiro, C., \& Leandrini, J. A. (2010). Abordagem interdisciplinar em bacias hidrográficas no Estado do Paraná. Campo Mourão, PR: Editora Fecilcam.

Pini, S. F. R., Abelha, M. C. F., Kashiwaqui, E. A. L., Delariva, R. L., Makrakis, S., Makrakis, M. (2019). Food resource partitioning among species of Astyanax (Characiformes: Characidae) in the Low Iguaçu River and tributaries, Brazil. Neotropical Ichthyology, 17, e190028.

Pujarra, S., Pandolfo, A., Lourenço, D. K., Gurski, F. A., Santos, A. P. A., \& Moretto, Y. (2017). Distribution of benthic communities in relation to the environmental integrity of subtropical streams. Ecología Austral, 27, 482-491.

Quirino, B. A., Carniatto, N., Gaiotto, J. V., \& Fugi, R. (2015). Seasonal variation in the use of food resources by small fishes inhabiting the littoral zone in a Neotropical floodplain lake. Aquatic Ecology, 49, 431-440.

Quirino, B. A., Carniatto, N., Guglielmetti, R., \& Fugi, R. (2017). Changes in diet and niche breadth of a small fish species in response to the flood pulse in a Neotropical floodplain lake. Limnologica, 62, 126-131.

R Core Team. (2019). R: A language and environment for statistical computing. Vienna, Austria: R Foundation for Statistical Computing. https://www.R-project.org/.

Schoener, T. W. (1968). The Anolis lizards of Bimini: resource partitioning in a complex fauna. Ecology, 49(4), 704-726. 
Silva, J. C., Gubiani, E. A., Neves, M. P., \& Delariva, R. L. (2017). Coexisting small fish species in lotic neotropical environments: Evidence of trophic niche differentiation. Aquatic Ecology, 51, 275-288.

Soares, S. D. A., Suarez, Y. R., Fernandes, W. D., Tenório, P. M. S., Delabie, J. H. C., \& Antonialli-Junior, W. F. (2013). Temporal variation in the composition of ant assemblages (Hymenoptera, Formicidae) on trees in the Pantanal floodplain, Mato Grosso do Sul, Brazil. Revista Brasileira de Entomologia, 57(1), 84-90.

Stephens, D. W., \& Krebs, J. R. (1986). Foraging theory. New Jersey, USA: Princeton University Press, Princeton.

Svanbäck, R., \& Bolnick, D. I. (2005). Intraspecific competition affects the strength of individual specialization: an optimal diet theory method. Evolutionary Ecology Research, 7, 993-1012.

Svanbäck, R., \& Bolnick, D. I. (2007). Intraspecific competition drives increased resource use diversity within a natural population. Proceedings of the Royal Society B: Biological Sciences, 274(1611), 839-844.

Terán, G. E., Benitez, M. F., \& Mirande, J. M. (2020). Opening the Trojan horse: phylogeny of Astyanax, two new genera and resurrection of Psalidodon (Teleostei: Characidae). Zoological Journal of the Linnean Society, XX, 1-18.

Tonin, A. M., Gonçalves, J. F., Bambi, P., Couceiro, S. R., Feitoza, L. A., Fontana, L. E., ... \& Lemes-Silva, A. L. (2017). Plant litter dynamics in the forest-stream interface: precipitation is a major control across tropical biomes. Scientific reports, 7(1), 10799. Van Valen, L. (1965). Morphological variation and width of ecological niche. The American Naturalist, 99(908), 377-390. 
Zaccarelli, N., Bolnick, D. I., \& Mancinelli, G. (2013). RInSp: an r package for the analysis of individual specialization in resource use. Methods in Ecology and Evolution, 4, 10181023. 


\section{TABLES}

Table 1. Results of permutational analysis of multivariate dispersions (PERMDISP) applied to diet data of the tetra fish (Pag=P. aff. gymnodontus; $\mathrm{Pap}=$ P.aff. paranae; $\mathrm{Pbi}=$ P. bifasciatus; $\mathrm{Bik}=$ B. ikaa.) collected during the winter and summer seasons. Average distance from the centroid (D), F statistics and $p$ values estimated by 9,999 randomizations. The significant $(p<0.05)$ effects are given in bold.

\begin{tabular}{|c|c|c|c|c|c|}
\hline \multirow{2}{*}{ Site } & \multirow{2}{*}{ Species } & \multicolumn{2}{|c|}{$\begin{array}{l}\text { Average distance to } \\
\text { centroid }\end{array}$} & \multirow{2}{*}{$\mathrm{F}$} & \multirow{2}{*}{$p$} \\
\hline & & Winter & Summer & & \\
\hline \multirow{2}{*}{$\mathrm{S} 1$} & $\mathrm{Pag}$ & 0.58 & 0.63 & $\mathrm{~F}_{1,89}=6.10$ & 0.010 \\
\hline & Pbi & 0.61 & 0.52 & $\mathrm{~F}_{1,37}=5.54$ & 0.028 \\
\hline \multirow{2}{*}{$\mathrm{S} 2$} & Pap & 0.35 & 0.61 & $\mathrm{~F}_{1,8}=11.67$ & 0.001 \\
\hline & $\mathrm{Pbi}$ & 0.6 & 0.58 & $\mathrm{~F}_{1,45}=0.20$ & 0.675 \\
\hline \multirow{2}{*}{$\mathrm{S} 3$} & Bik & 0.52 & 0.59 & $\mathrm{~F}_{1,29}=1.90$ & 0.196 \\
\hline & $\mathrm{Pbi}$ & 0.53 & 0.58 & $\mathrm{~F}_{1,74}=3.78$ & 0.053 \\
\hline $\mathrm{S} 4$ & $\mathrm{Pbi}$ & 0.55 & 0.55 & $\mathrm{~F}_{1,31}=0.00$ & 0.985 \\
\hline S5 & $\mathrm{Pbi}$ & 0.58 & 0.57 & $F_{1,34}=0.04$ & 0.825 \\
\hline S6 & $\mathrm{Pbi}$ & 0.6 & 0.6 & $F_{1,38}=0.00$ & 0.970 \\
\hline
\end{tabular}


Table 2 Effects of seasonality, presence of interspecific competitors, and their interaction on the population trophic niche breadth (D: distance to centroid) and PSi values of the Psalidodon bifasciatus in neotropical headwater streams, southern Brazil, in the winter and summer seasons. The significant $(p<0.05)$ effects are given in bold.

\begin{tabular}{lccccc}
\hline Predictor & \multicolumn{3}{c}{ Trophic niche breadth (D) } & & Individual sp \\
\cline { 2 - 3 } \cline { 5 - 5 } & \multicolumn{2}{c}{ Estimate (SE) } & $z$ & $p$ & Estimate (SE) \\
Intercept & $0.29(0.06)$ & 4.65 & $<\mathbf{0 . 0 0 1}$ & & $-1.07(0.19)$ \\
Season & $0.01(0.09)$ & 0.15 & 0.88 & $-0.99(0.16)$ \\
Number of co-ocurring species & $-0.05(0.09)$ & -0.60 & 0.55 & $0.39(0.22)$ \\
Interaction & $0.07(0.12)$ & 0.54 & 0.59 & $-0.14(0.26)$ \\
\hline
\end{tabular}


Table 3 Effects of seasonality on PSi values of the tetra fish (Pag=P. aff. gymnodontus; Pap $=$ P.aff. paranae $; \mathrm{Pbi}=P$. bifasciatus $; \mathrm{Bik}=$ B. ikaa. ) collected in neotropical headwater streams, southern Brazil, in the winter and summer of 2017. We modelled PSi values of species with beta regression (R function betareg). Model: PSi $\sim$ Season*Species. The significant $(p<0.05)$ effects are given in bold.

\begin{tabular}{lccc}
\hline Predictor variable & Estimate (SE) & $z$ & $p$ \\
\hline Intercept & $-0.63(0.12)$ & -5.46 & $<\mathbf{0 . 0 0 1}$ \\
Season (Summer) & $-0.33(0.18)$ & -1.84 & 0.066 \\
Species (Pap) & $1.07(0.41)$ & 2.64 & $\mathbf{0 . 0 0 8}$ \\
Species (Pbi) & $-0.30(0.14)$ & -2.09 & $\mathbf{0 . 0 3 7}$ \\
Species (Bik) & $0.24(0.25)$ & 0.97 & 0.331 \\
Season (Summer): Species (Pap) & $-1.09(0.59)$ & -1.85 & 0.065 \\
Season (Summer): Species (Pbi) & $0.48(0.21)$ & 2.28 & $\mathbf{0 . 0 2 3}$ \\
Season (Summer): Species (Bik) & $-0.17(0.37)$ & -0.46 & 0.647 \\
\hline
\end{tabular}




\section{FIGURE LEGENDS}

Figure 1 Species studied: (A) Psalidodon aff. gymnodontus (UFRGS 25725, $95.4 \mathrm{~mm}$ SL); (B) Psalidodon aff. paranae (UFRGS 26232, 48.0 mm LS); (C) Psalidodon bifasciatus (UFRGS 26235, $85.0 \mathrm{~mm}$ SL) and (D) Bryconamericus ikaa (UFRGS 26246, $49.0 \mathrm{~mm} \mathrm{SL).}$

Figure 2 A) Boxplot of population trophic niche breadth (estimated as distance to centroid, PERMDISP) of $P$. bifasciatus (Pbi) in streams with co-occurring characid species (S1, S2 and S3) and in allopatry (S4, S5 and S6). B) population trophic niche breadth of three characid fish species (Pag= P. aff. gymnodontus; Pap= P.aff. paranae) in co-occurrence with $P$. bifasciatus collected during the winter and summer seasons. Box lower and upper endpoints represent the 25th and 75th quartiles, respectively. The horizontal bar inside each box represent median diet breadth.

Figure 3 A) Differences in individual specialization (V) of $P$. bifasciatus (Pbi) in streams with co-occurring characid species (S1, S2 and S3) and in allopatry (S4, S5 and S6). B) in individual specialization (V) of three characid fish species (Pag= $P$. aff. gymnodontus; Pap= P.aff. paranae) in co-occurrence with $P$. bifasciatus collected during the winter and summer seasons. Error bars were generated based on observed values of 1-PSi.

Figure 4 Schematic summary of the effects of seasonality in variation niche and individual specializations of the tetra fish in Neotropical headwater streams, southern 
Brazil. In the winter (dry season), P. bifasciatus tends to expand its population niche via increased between-individual variation (different colours). In the summer (wet season), $P$. aff. gymnodontus, $P$. aff. paranae and $B$. ikaa tends to expand their population niches via increased between-individual variation (different colours). Small circles indicate niche contraction and homogenous diet among individuals. 


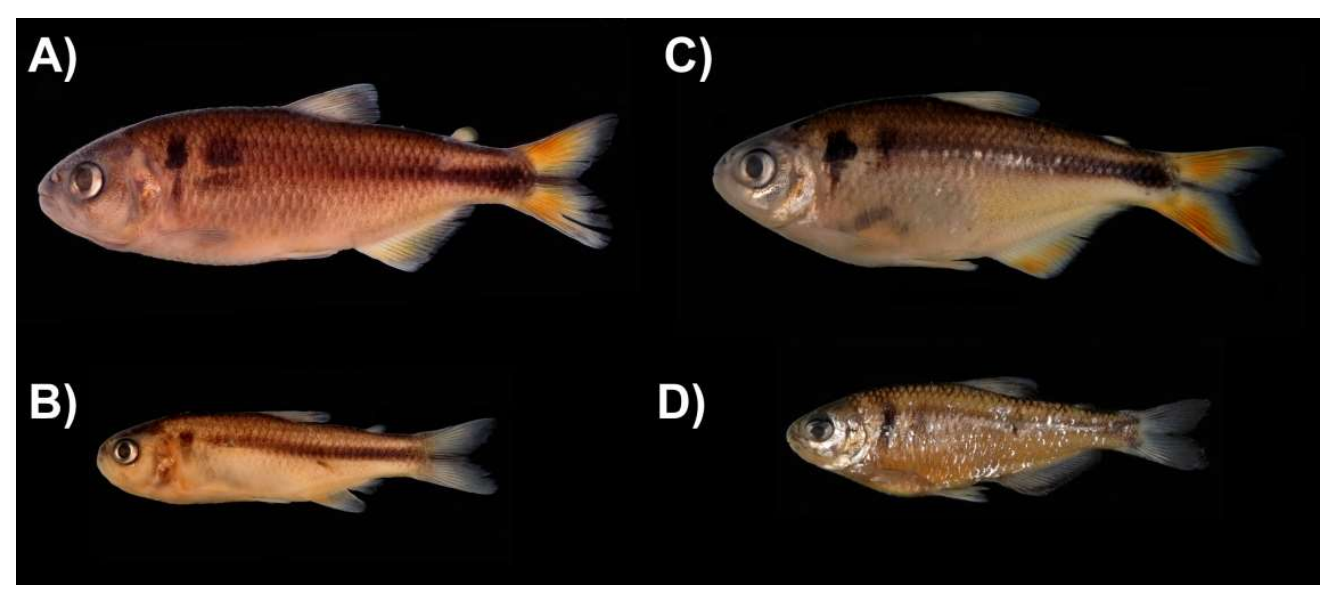

$230 \times 99 \mathrm{~mm}(300 \times 300 \mathrm{DPI})$ 

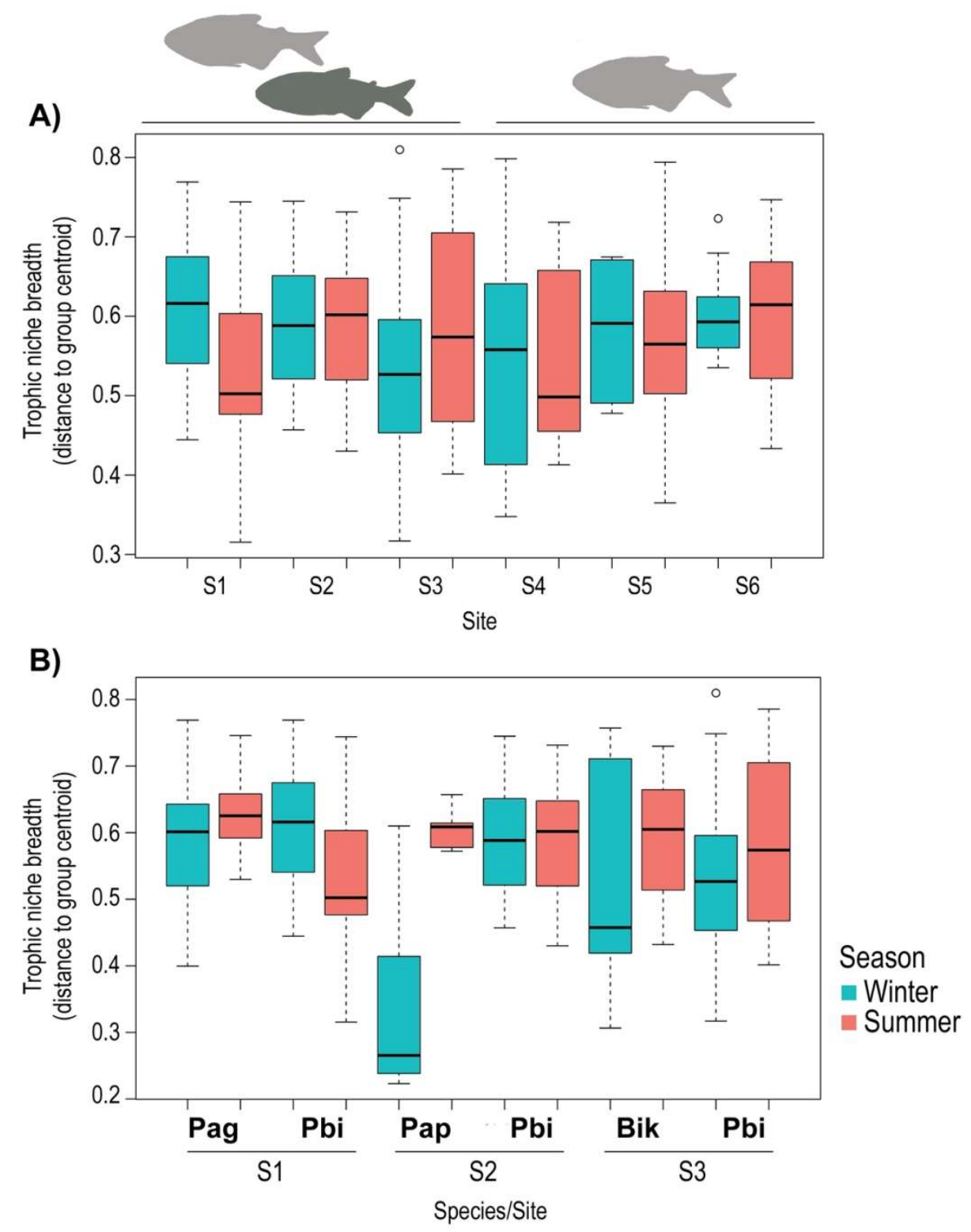

$109 \times 139 \mathrm{~mm}(300 \times 300$ DPI) 

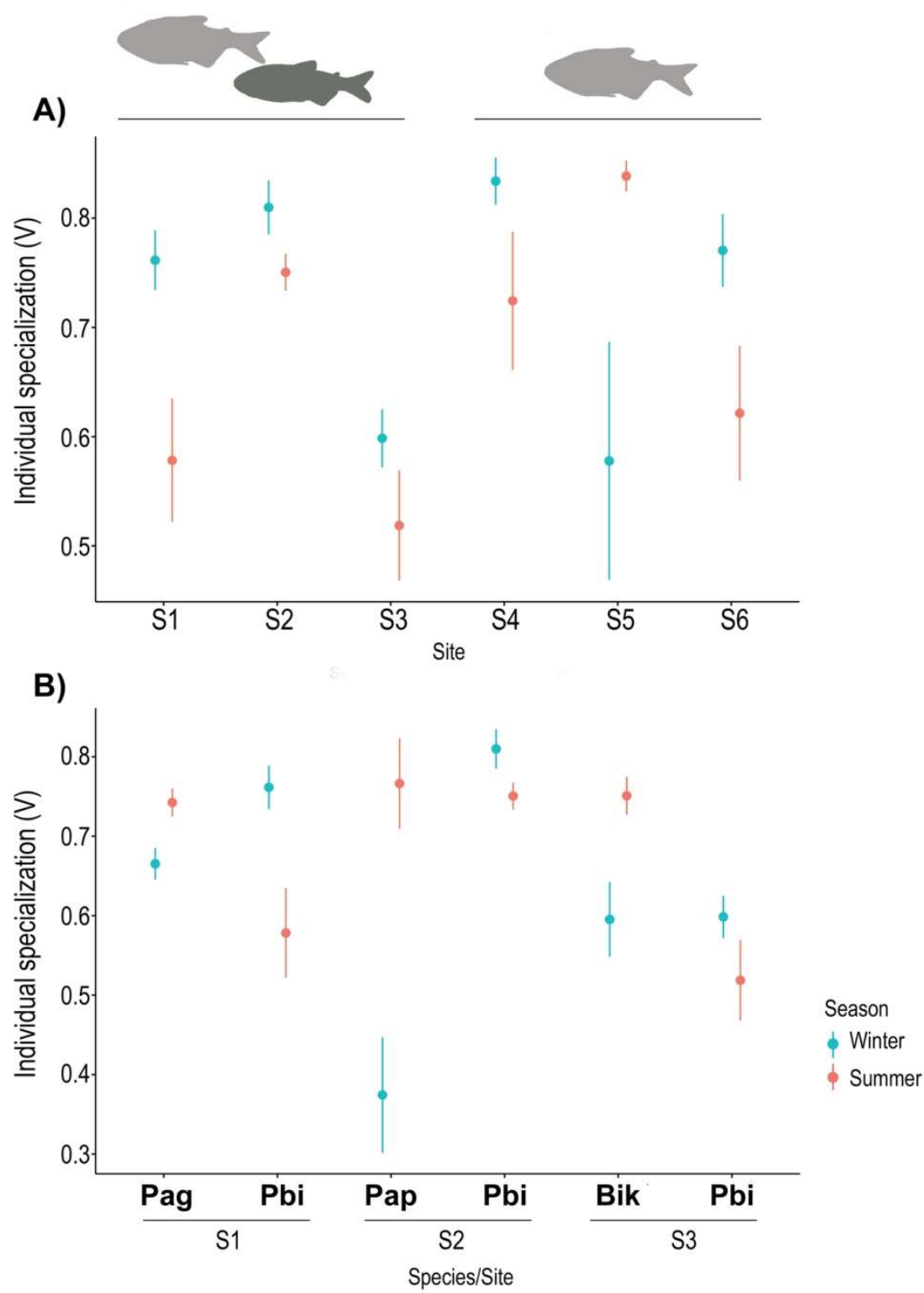

$114 \times 159 \mathrm{~mm}(300 \times 300$ DPI) 


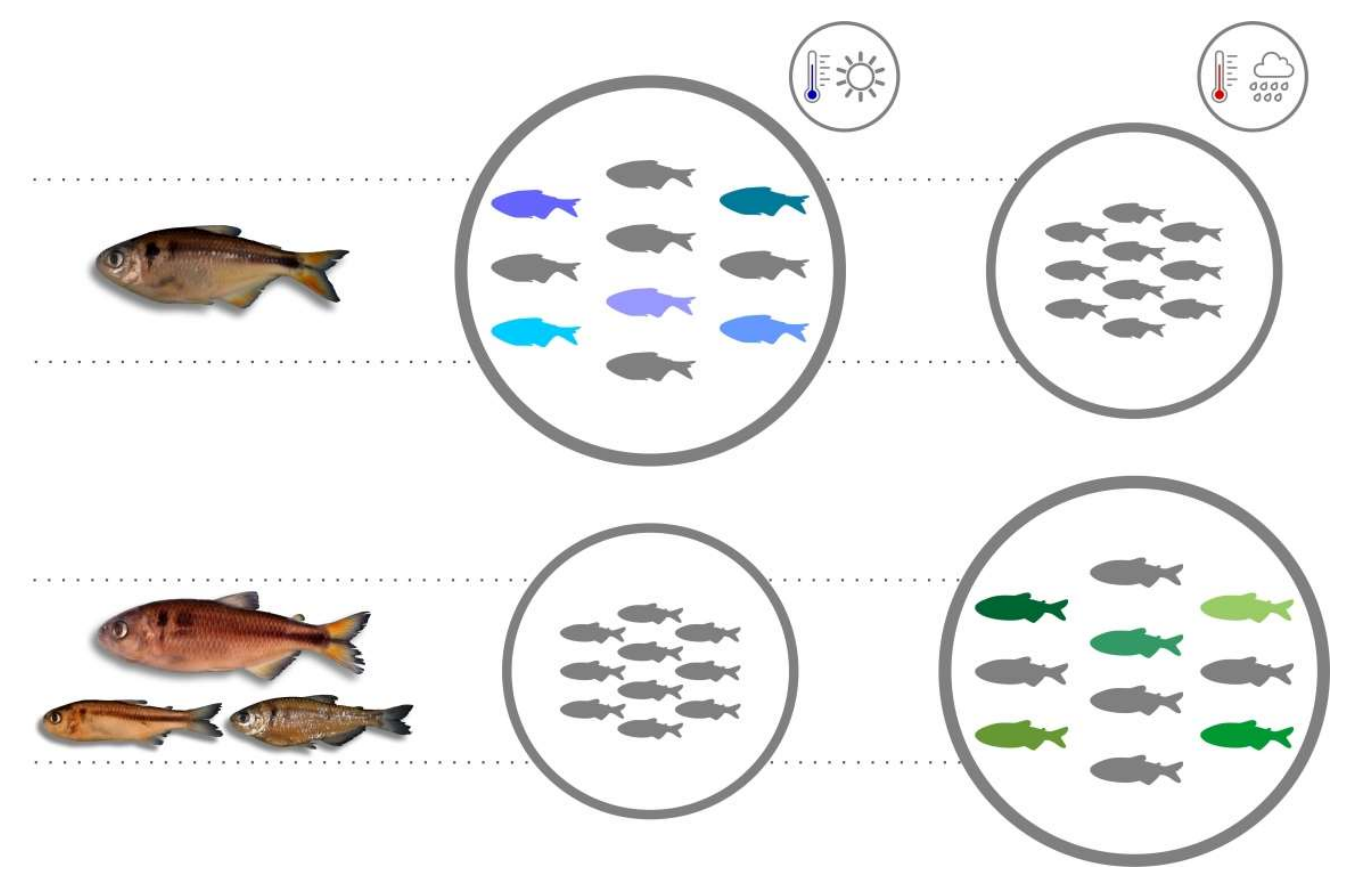




\title{
Seasonality and interspecific competition shape individual niche variation in co-occurring tetra fishes in Neotropical streams
}

\author{
Mayara Pereira Neves ${ }^{1,2}$, Raul Costa-Pereira ${ }^{3,4}$, Rosilene Luciana Delariva ${ }^{5}$, Clarice \\ Bernhardt Fialho ${ }^{1}$
}

${ }^{1}$ Pós-Graduação em Biologia Animal, Laboratório de Ictiologia, Departamento de Zoologia, Instituto de Biociências, Universidade Federal do Rio Grande do Sul, Campus do Vale, Avenida Bento Gonçalves, 9500, Agronomia, 91501-970, Porto Alegre, RS, Brazil

${ }^{2}$ School of Biological and Chemical Sciences, Queen Mary University of London, London, United Kingdom

${ }^{3}$ Departamento de Biologia Animal, Instituto de Biologia, CP 6109, Universidade Estadual de Campinas - Unicamp, 13083-970, Campinas, SP, Brazil

${ }^{4}$ Evolutionary Ecology (EE), Center for Ecology, Evolution and Environmental Sciences (ce3c), Lisboa, Portugal

${ }^{5}$ Laboratório de Ictiologia, Ecologia e Biomonitoramento, Universidade Estadual do Oeste do Paraná, Centro de Ciências Biológicas e da Saúde, Rua Universitária 2069, 85819-110. Cascavel, PR, Brazil 


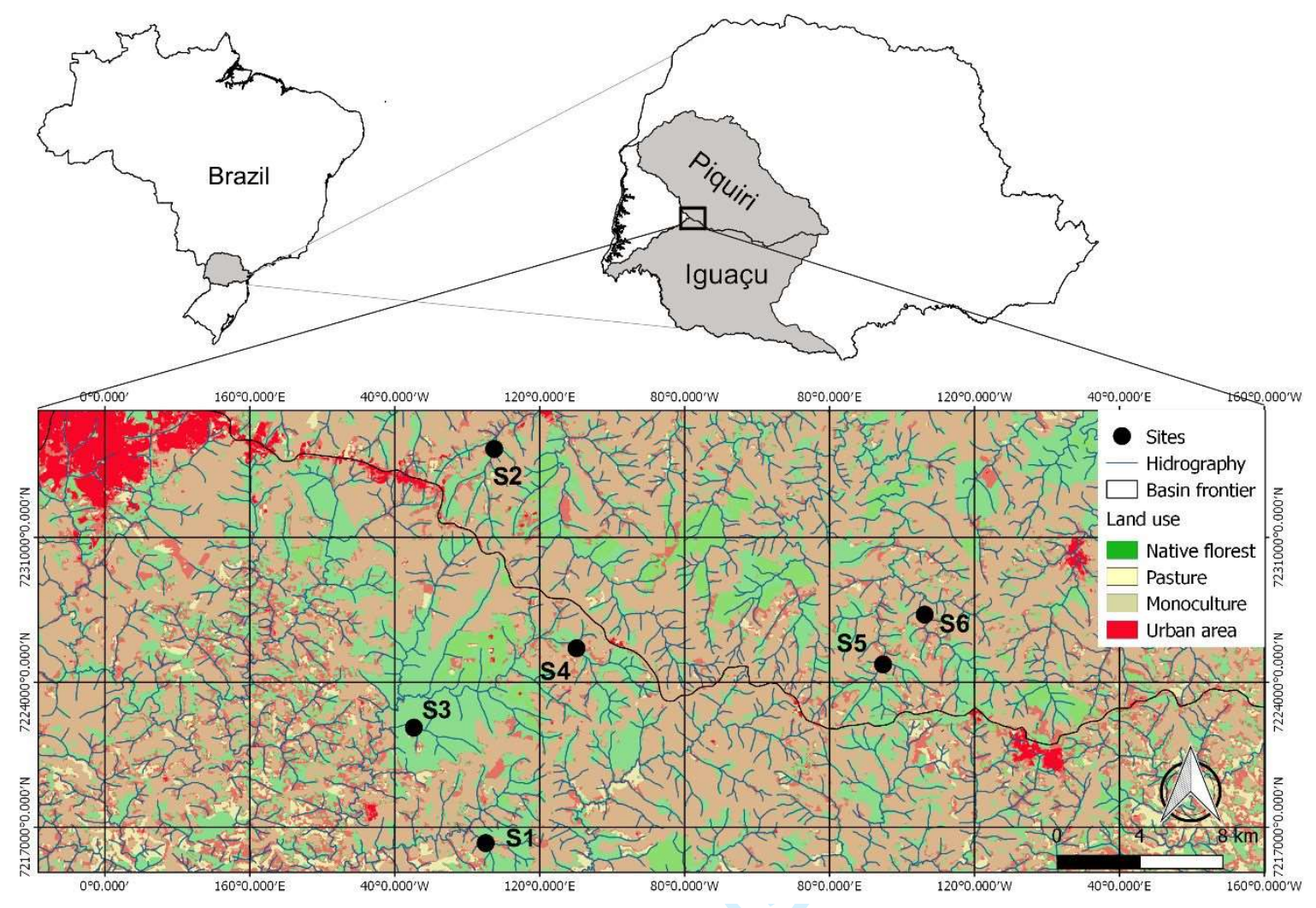

FIGURE S1 Study area highlighted from the hydrographic map of the Paraná State, southern Brazil. Lower Iguaçu River basin: S1, S3 and S4. Piquiri River basin: S2, S5 and S6. 


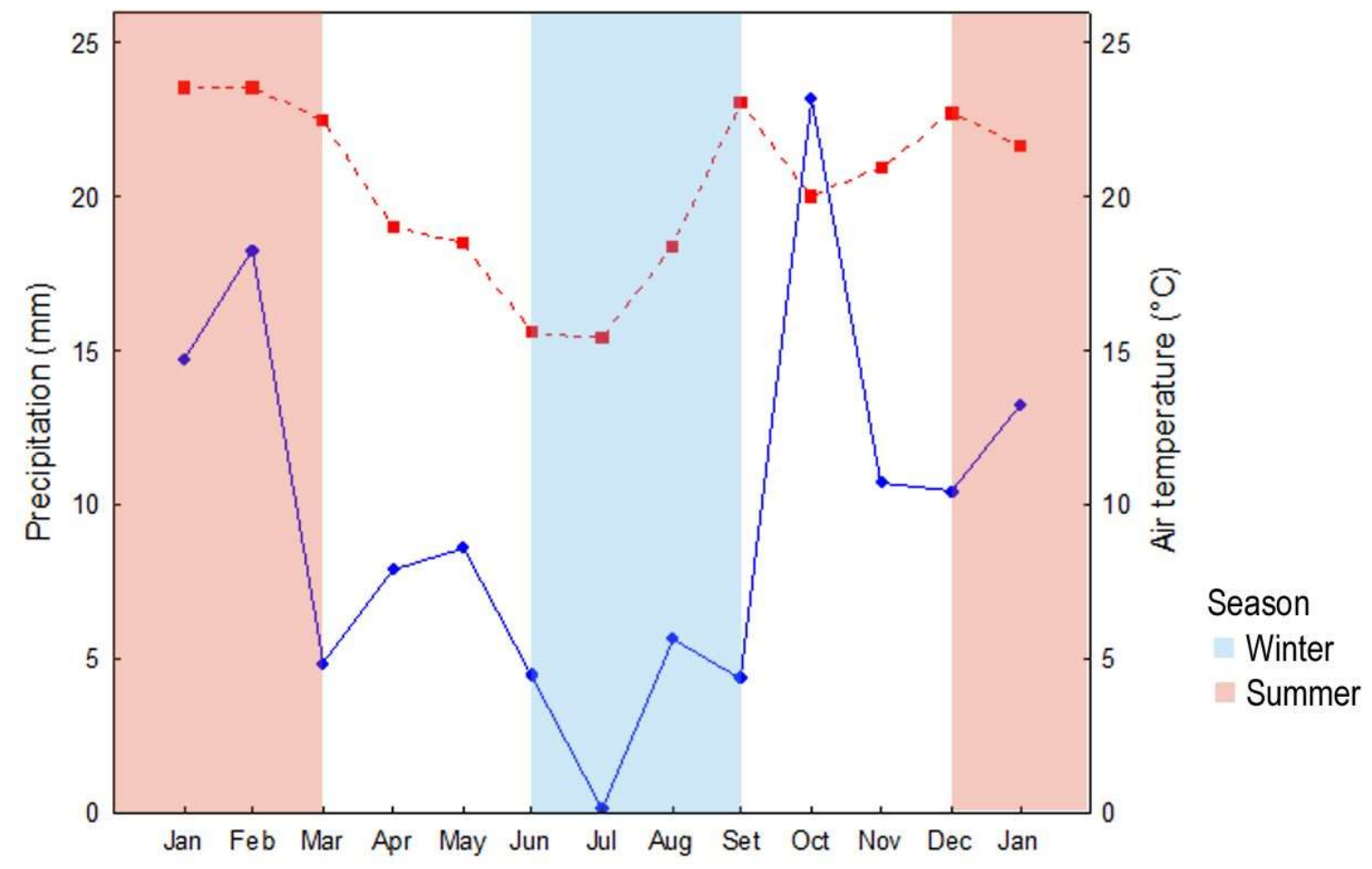

FIGURE S2 Average monthly precipitation (blue circle) and air temperature (red square) in the city of Cascavel, western region of the state of Paraná, southern Brazil, between January 2017 and January 2018. (data were provided by the Paraná Weather System [Simepar] from the Cascavel weather station). 


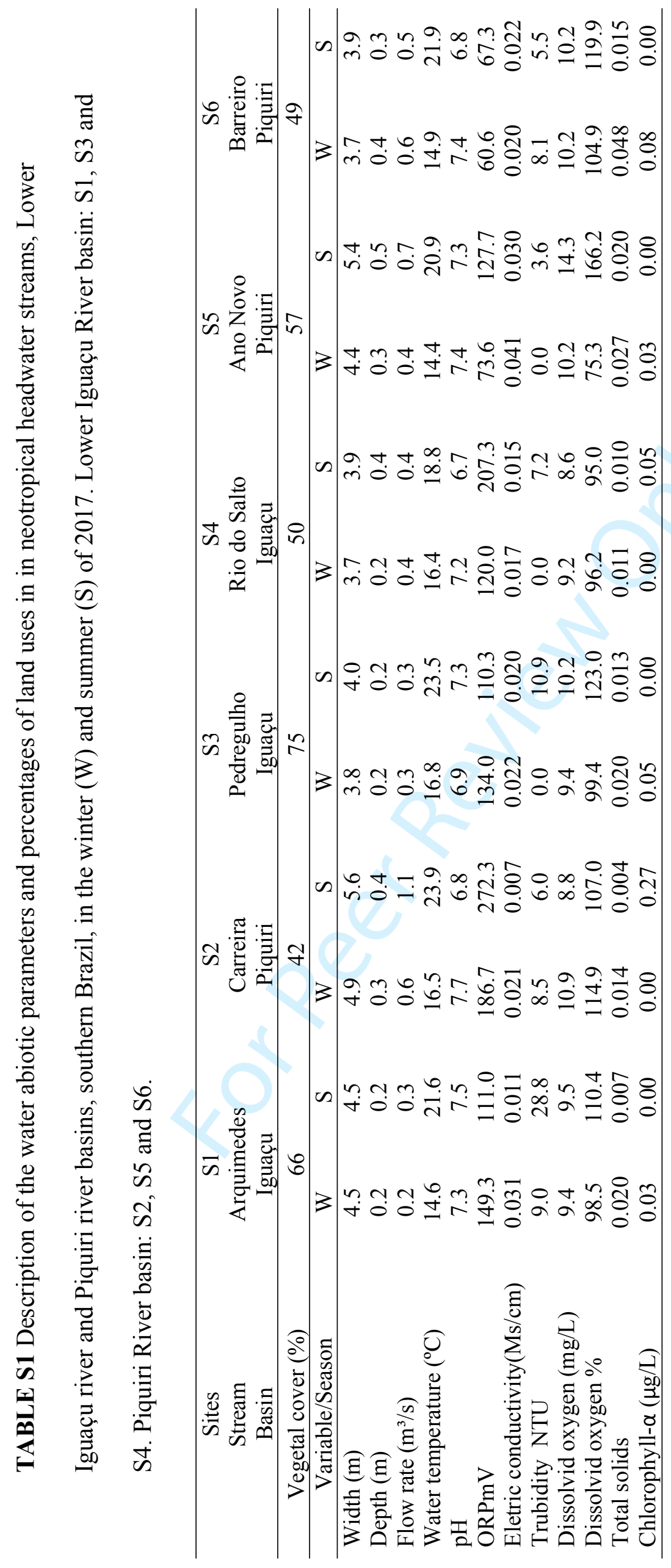

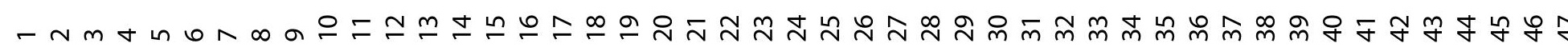


TABLE S2 Feeding items (\%) according to their origin consumed by the tetra fish in neotropical headwater streams, Lower Iguaçu river and Piquiri river basins, southern Brazil, in the winter (W) and summer (S) of 2017.Values based on volume data as a percentage of feeding items. Codes: $\mathrm{SD}=$ Standard deviation; $\mathrm{cm}=$ centimeters, $\mathrm{g}=$ grams. Asterisk indicates values below $0.1 \%$. The most consumed feeding items are in bold.

\begin{tabular}{|c|c|c|c|c|c|c|c|c|}
\hline \multirow{2}{*}{$\begin{array}{l}\text { Species } \\
\text { Standard length }(\mathrm{cm} \text {, } \\
\text { Mean } \pm \text { SD })\end{array}$} & \multicolumn{2}{|c|}{$\begin{array}{l}\text { Psalidodon aff. } \\
\text { gymnodontus }\end{array}$} & \multicolumn{2}{|c|}{$P$. aff. parane } & \multicolumn{2}{|c|}{ P. bifasciatus } & \multicolumn{2}{|c|}{ B. ikaa } \\
\hline & \multicolumn{2}{|c|}{$8.8 \pm 1.2$} & \multicolumn{2}{|c|}{$4.7 \pm 0.6$} & \multicolumn{2}{|c|}{$6.2 \pm 1.6$} & \multicolumn{2}{|c|}{$4.2 \pm 0.7$} \\
\hline Weight (g, Mean \pm SD) & \multicolumn{2}{|c|}{$19.5 \pm 8.2$} & \multicolumn{2}{|c|}{$2.1 \pm 0.9$} & \multicolumn{2}{|c|}{$6.8 \pm 5.3$} & \multicolumn{2}{|c|}{$1.5 \pm 0.6$} \\
\hline Season & $\mathrm{W}$ & $\mathrm{S}$ & $\mathrm{W}$ & $\mathrm{S}$ & $\mathrm{W}$ & $\mathrm{S}$ & W & $\mathrm{S}$ \\
\hline Stomach analysed & 56 & 32 & 5 & 5 & 116 & 153 & 16 & 15 \\
\hline Autochthonous & 19.6 & 18.4 & 61.4 & 33.8 & 41.5 & 18 & 86.6 & 53.1 \\
\hline Testate Amoebae & & & & & & $*$ & & 0.3 \\
\hline Nematoda & $*$ & & & 0.1 & $*$ & 0.1 & & \\
\hline Bivalvia & & & & & & & & 0.8 \\
\hline Acarina & $*$ & & & & & $*$ & & \\
\hline Conchostracoda & & & & & & $*$ & & \\
\hline Atyidae & 0.4 & & & & 7.8 & 0.2 & & \\
\hline Aegla sp. & 0.9 & 5.5 & & & 0.3 & & & \\
\hline Ephemeroptera & 0.1 & 2.1 & 10.5 & 1.3 & 2.5 & 1.3 & 44.7 & 18.2 \\
\hline Odonata & 2.1 & & & & 2.3 & 0.3 & & 4 \\
\hline Plecoptera & $*$ & 0.5 & & & 0.1 & $*$ & & \\
\hline Hemiptera & & & & & 0.1 & & & \\
\hline Coleoptera & 0.3 & 0.3 & 1.8 & 1.3 & 0.8 & 0.6 & 4.3 & 1.1 \\
\hline Trichoptera & 5.9 & $*$ & & 8 & 2.8 & 0.6 & 19.6 & 16 \\
\hline Diptera (larvae and pupae) & 1.2 & 1.2 & & & 1.3 & $*$ & 0.4 & 0.3 \\
\hline Ceratopogonidae & $*$ & & & 0.1 & 0.1 & $*$ & 0.3 & 0.2 \\
\hline Chironomidae & 0.5 & 0.3 & 1.8 & 2.8 & 0.6 & 0.1 & 0.2 & 5.1 \\
\hline Simuliidae & 0.2 & 0.1 & 1.8 & 9.4 & 0.4 & 1.1 & 1.5 & 1.6 \\
\hline $\begin{array}{l}\text { Lepidoptera (larvae and } \\
\text { pupae) }\end{array}$ & 0.5 & 5.1 & & & 1.9 & 9.1 & 6.9 & 1.6 \\
\hline Aquatic insect remains & 5.4 & 3.2 & 45.6 & 10.7 & 14.3 & 3.9 & 8.8 & 4 \\
\hline
\end{tabular}


Scales

Diatoms

Filamentous algae

\begin{tabular}{|c|c|c|c|c|c|c|c|c|}
\hline Aquatic plant & & 0.2 & & & 6.1 & 0.7 & & \\
\hline Allochthonous & 73.6 & 70.2 & 38.6 & 55.5 & 37.2 & 75.7 & 10.4 & 20.3 \\
\hline Oligochaeta & & & & & 0.1 & & 3.3 & 4.8 \\
\hline Aranae & & 1.7 & & & 0.7 & 0.4 & & 1.9 \\
\hline Oniscidae & & & & & 2.3 & & & \\
\hline Plecoptera & & & & & 0.4 & 0.1 & & \\
\hline Auchenorrhyncha & 1 & & & 13.4 & 2 & 0.3 & & \\
\hline Coleoptera & 8.2 & 22.2 & 1.8 & 34.1 & 5 & 4.2 & 0.4 & 0.3 \\
\hline Diptera & 3.8 & & & 2.7 & 0.2 & & 1.6 & \\
\hline Lepidoptera & 0.3 & 3.1 & & & 0.8 & 0.1 & & \\
\hline Hymenoptera & 2.2 & 12.1 & 29.8 & 2.7 & 10.5 & 3.7 & 2.2 & 2.9 \\
\hline Terrestrial insect remains & 1.4 & 2.5 & & 2.7 & 1.1 & 1.5 & 2.9 & \\
\hline Leaves & 29.9 & 12.2 & 7 & & 9.1 & 4.1 & & \\
\hline Seeds & 26.7 & 16.4 & & & 5 & 61.3 & & 10.4 \\
\hline Undetermined & 6.7 & 11.3 & 8 & 10.7 & 20.5 & 6.2 & 2.9 & 26.6 \\
\hline Sediment/Detritus & 6.7 & 11.3 & $P$ & 10.7 & 20.5 & 6.2 & 2.9 & 26.6 \\
\hline
\end{tabular}




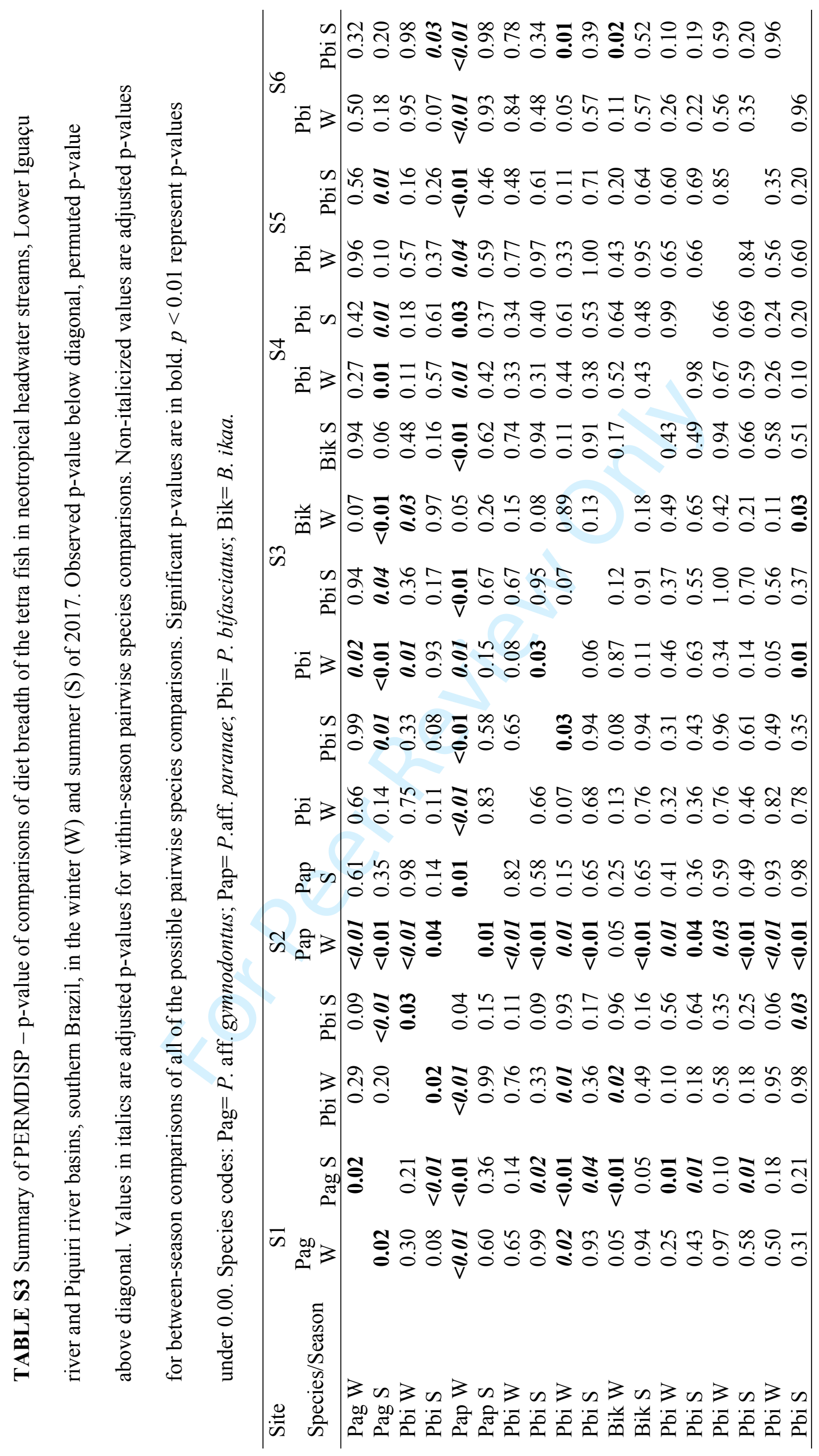


TABLE S4 Values obtained through the SIMPER analysis based in the diet of the tetra fish in neotropical headwater streams, Lower Iguaçu river and Piquiri river basins, southern Brazil, in the winter (W) and summer (S) of 2017. Codes: SD= Standard deviation. Most average groups are highlighted in bold.

\begin{tabular}{|c|c|c|c|c|c|c|c|c|}
\hline Site & Species & Feeding items & Average & $\mathrm{SD}$ & Ratio & $\begin{array}{c}\text { Average } \\
\text { W }\end{array}$ & $\begin{array}{l}\text { Average } \\
\text { S }\end{array}$ & $\begin{array}{l}\text { Cumulative } \\
\text { contribution }\end{array}$ \\
\hline \multirow{6}{*}{ S1 } & \multirow{3}{*}{$\begin{array}{l}\text { Psalidodon } \\
\text { aff. } \\
\text { gymnodontus }\end{array}$} & Seeds & 0.18 & 0.22 & 0.84 & 0.025 & 0.016 & 0.21 \\
\hline & & Leaves & 0.17 & 0.2 & 0.87 & 0.028 & 0.012 & 0.41 \\
\hline & & Coleoptera adult & 0.12 & 0.21 & 0.57 & 0.008 & 0.021 & 0.54 \\
\hline & \multirow{3}{*}{ P. bifasciatus } & Seeds & 0.19 & 0.22 & 0.87 & 0.009 & 0.019 & 0.22 \\
\hline & & Leaves & 0.17 & 0.19 & 0.91 & 0.014 & 0.01 & 0.41 \\
\hline & & Sediment/Detritus & 0.12 & 0.17 & 0.68 & 0.016 & 0.001 & 0.55 \\
\hline \multirow{8}{*}{$\mathbf{S 2}$} & \multirow{3}{*}{$P$. aff paranae } & $\begin{array}{l}\text { Aquatic insects } \\
\text { remains }\end{array}$ & 0.26 & 0.24 & 1.08 & 0.005 & 0.001 & 0.29 \\
\hline & & Hymnoptera & 0.14 & 0.12 & 1.16 & 0.003 & 0 & 0.45 \\
\hline & & Coleoptera adult & 0.11 & 0.23 & 0.49 & 0 & 0.004 & 0.58 \\
\hline & \multirow{5}{*}{ P. bifasciatus } & Sediment/Detritus & 0.16 & 0.23 & 0.7 & 0.015 & 0.005 & 0.18 \\
\hline & & Ephemeroptera & 0.09 & 0.17 & 0.57 & 0.009 & 0.002 & 0.28 \\
\hline & & $\begin{array}{l}\text { Aquatic insects } \\
\text { remains }\end{array}$ & 0.08 & 0.09 & 0.86 & 0.006 & 0.003 & 0.37 \\
\hline & & Aquatic plant & 0.06 & 0.22 & 0.29 & 0.023 & 0 & 0.44 \\
\hline & & Seeds & 0.06 & 0.14 & 0.45 & 0 & 0.011 & 0.51 \\
\hline \multirow{6}{*}{ S3 } & \multirow{3}{*}{ B. ikaa } & Ephemeroptera & 0.26 & 0.23 & 1.13 & 0.014 & 0.005 & 0.3 \\
\hline & & Trichoptera larvae & 0.14 & 0.18 & 0.77 & 0.006 & 0.004 & 0.46 \\
\hline & & Sediment/Detritus & 0.08 & 0.13 & 0.63 & 0 & 0.004 & 0.55 \\
\hline & \multirow{3}{*}{ P. bifasciatus } & Seeds & 0.31 & 0.32 & 0.99 & 0.001 & 0.156 & 0.35 \\
\hline & & $\begin{array}{l}\text { Aquatic insects } \\
\text { remains }\end{array}$ & 0.12 & 0.15 & 0.84 & 0.019 & 0.004 & 0.49 \\
\hline & & Hymnoptera & 0.12 & 0.15 & 0.82 & 0.016 & 0.007 & 0.62 \\
\hline \multirow{3}{*}{ S4 } & \multirow{3}{*}{ P. bifasciatus } & Sediment/Detritus & 0.19 & 0.21 & 0.91 & 0.006 & 0.006 & 0.22 \\
\hline & & Seeds & 0.18 & 0.31 & 0.57 & 0 & 0.018 & 0.43 \\
\hline & & Ephemeroptera & 0.08 & 0.21 & 0.4 & 0.001 & 0.005 & 0.53 \\
\hline \multirow{3}{*}{ S5 } & \multirow{3}{*}{ P. bifasciatus } & Seeds & 0.18 & 0.3 & 0.61 & 0.001 & 0.014 & 0.2 \\
\hline & & Sediment/Detritus & 0.17 & 0.22 & 0.77 & 0.002 & 0.008 & 0.39 \\
\hline & & $\begin{array}{l}\text { Aquatic insects } \\
\text { remains }\end{array}$ & 0.16 & 0.19 & 0.82 & 0.004 & 0.005 & 0.57 \\
\hline \multirow{3}{*}{ S6 } & \multirow{3}{*}{ P. bifasciatus } & Seeds & 0.31 & 0.36 & 0.86 & 0.001 & 0.107 & 0.33 \\
\hline & & $\begin{array}{l}\text { Aquatic insects } \\
\text { remains }\end{array}$ & 0.1 & 0.13 & 0.78 & 0.008 & 0.005 & 0.43 \\
\hline & & Hymnoptera & 0.09 & 0.18 & 0.51 & 0.006 & 0.007 & 0.53 \\
\hline
\end{tabular}


